\title{
The Juscelino Kubitschek government and the Brazilian Malaria Control and Eradication Working Group: collaboration and conflicts in Brazilian and international health agenda, 1958-1961
}

Renato da Silva

Professor, Programa de Mestrado de Letras e Ciências Humanas/Unigranrio.

Rua Prof. José de Souza Herdy, 1160, Jardim 25 de Agosto 25071-202 - Duque de Caxias - RJ - Brasil

redslv@hotmail.com

\section{Carlos Henrique Assunção Paiva}

Pesquisador, Casa de Oswaldo' Cruz/Fiocruz; professor, Programa de Mestrado em Saúde Global e Diplomacia em Saúde/Fiocruz e Mestrado em Saúde da Família/Universidade Estácio de Sá. Av. Brasil, 4036, sala 416-A

21040-361- Rio de Janeiro - RJ - Brasil

cpaiva@coc.fiocruz.br

Received for publication in July 2013.

Approved for publication in May 2014.

Translated by Derrick Guy Phillips.
SILVA, Renato da; PAIVA, Carlos Henrique Assunção. The Juscelino Kubitschek government and the Brazilian Malaria Control and Eradication Working Group: collaboration and conflicts in Brazilian and international health agenda, 1958-1961. História, Ciências, Saúde Manguinhos, Rio de Janeiro, v.22, n.1, jan.-mar. 2015. Available at: http://www. scielo.br/hcsm.

\section{Abstract}

Malaria, a disease which was under control in the beginning of Juscelino Kubitschek government, became the most important endemic disease in 1958, when Brazil made a commitment with the World Health Organization to convert its control programs into eradication programs. For this purpose a Malaria Control and Eradication Group was set up under the leadership of the malaria specialist Mário Pinotti. Malaria would become an important bargaining chip in the context of the development policies of Kubitschek. This article focuses on path of the Malaria Control and Eradication Working Group in Brazil, in its varying relationships with the arguments and guidelines established at international level.

Keywords: World Health Organization; Juscelino Kubitschek (1902-1976); public health; malaria; Mário Pinotti (1894-1972). 
$\mathrm{T}$ he discovery of the residual properties of dichloro-diphenyl-trichloroethane (DDT) during the Second World War, and its mass use after the end of the conflict, produced a favorable and optimistic environment with regard to the eradication of diseases transmitted by insects, such as malaria. Discussions among the community of malaria specialists occurred more frequently in the 1950s, and were echoed in Pan-American Health Conferences, Regional Meetings of the Malaria Specialists Committee and World Health Meetings. According to J. Jackson (1998, p.193), the need for a malaria eradication program on a global scale was conceived at the meetings of this community.

In 1950, at the $13^{\text {th }}$ Pan-American Conference on Health, the conclusion reached was that "Through the adoption of new techniques in the struggle against malaria and the efforts of member-states and territories, the total eradication of malaria can be achieved" (Brasil, 1966, p.2).

The Pan-American Health Office was a pioneer in the conviction that it was possible to eradicate malaria. It encouraged existing programs, promoted the exchange of ideas, and supplied technical assistance and, in many cases, financial assistance, with the aim of achieving the eradication of malaria throughout the Americas (Brasil, 1967, p.2). A large part of the enthusiasm displayed by the Pan-American Health Office - as from 1958, the Pan-American Health Organization (PAHO) - came from the fact that its director between 1947 and 1959 was Fred L. Soper, who worked for more than a decade in Brazil and was in charge of the campaign which eradicated Anopheles gambiae in the North-East region of Brazil. Based on this experience, he became one of the authors of the idea of eradication (Cueto, 2004).

At the $14^{\text {th }}$ Pan-American Conference on Health, held in 1954 in Santiago, Chile, it was recommended that countries should convert their control programs into eradication campaigns. In 1955, at the Eighth World Health Meeting, held in Mexico City, a resolution was approved recommending member-states to aim at the eradication of malaria before the carrier species became resistant to insecticides. The World Health Organization (WHO) took the initiative by supplying technical assistance and incentives for national programs (Cueto, 2004, p.3).

The $14^{\text {th }}$ Pan-American Conference on Health (1954) and the $8^{\text {th }}$ World Health Meeting (1955) added to the debate over the increased resistance to DDT shown by carrier insects when it was used over a long period. The resistance scenario augmented the need for the eradication of malaria (Packard, 1998, p.217). These two international health meetings can be considered as markers in the eradication of malaria at global level. The main proposal which arose from these events was the recommendation that member-states of the WHO should transform their malaria control programs into eradication programs as quickly as possible (Rachou, 1956, p.8-9). The start of the process to convert existing malaria control programs in Brazil into a Malaria Eradication Campaign (MEC) would only occur at the end of the 1950s (Brasil, 1967, p.3).

An understanding of the term "eradication" was essential for the development of programs which aimed to end malaria. According to Rita B. Barata (1998, p.64), the idea was proposed at the Fourth International Congress on Tropical Medicine and Malaria in 1948. The concept was the result of experience acquired in control programs in Greece, Venezuela and the USA. An attempt to eradicate Anopheles labranchiae (one of the carriers of malaria) in 
Sardinia was not successful. The program then changed its strategy, no longer focusing on the carrier but on the malaria parasite. The new tactics consisted in an all-out fight against the mosquitoes responsible for infection, through an eradication of the parasites in the insect population (Brown, 1998, p.128). The distinction between "control" and "eradication" was finally established by the Malaria Experts Committee of the WHO in 1955. According to the Committee, in control programs the objective was to reduce transmission to an acceptable degree, while in eradication programs the aim was to end the disease (Brasil, 1967, p.2).

In 1956, the Sixth Report of the WHO Malaria Committee set out the guidelines for transforming control programs into eradication programs (Pampana, 1966, p.303). Campaigns should adhere to the following principles: the total and ongoing elimination of transmission in all areas where it might occur; exclusive operations, the costs of which should be seen as an investment, and not as a permanent item of expenditure; and the diagnosis and classification of all cases, together with periodic epidemiological and administrative evaluations. ${ }^{1}$

Using the typical vocabulary of the so-called "campaigning health care," which tends to employ military imagery, the Malaria Program, in its "attack stage," was to concentrate on two main objectives: "attack operations" and "evaluation operations." The attack operations would strictly speaking be the eradication programs involving the spraying of residual insecticide in every home in a malaria area until transmission was interrupted. The minimum duration of the attack stage was to be three years and might extend to seven years. In some exceptional cases the attack operations could consist in anti-larval measures, with or without the spraying of homes, and the intensive use of prophylactic medicines. Evaluation operations would consist in surveys of malaria infection in positive cases and areas, i.e. research carried out on individuals and areas with malaria. According to Pampana (1966, p.304), these evaluation operations would be the responsibility of the national malaria eradication services of each country.

The scheme for malaria eradication planned by the WHO established two criteria, which all countries had to follow, in order to stop DDT spraying operations: firstly, surveillance operations should cover a large and continuous area, and should show a complete interruption of transmission in that area; secondly, there must be no cases of malaria in children. However, there would be a tolerance for recent indigenous cases. In 1964, the Malaria Specialists Committee of the WHO adopted the following criteria: In order to stop the spraying of homes with insecticide, it must be verified that, within a period of 12 months, the number of cases has not exceeded 0.1\% among every one thousand inhabitants (Pampana, 1966, p.306).

The eradication consolidation stage would begin after there had been total coverage with residual insecticide in the malaria-affected area, bringing an end to the attack stage. According to the Sixth Bulletin of the WHO Malaria Committee (Pampana, 1966, p.307), this stage would come to an end after three years of active surveillance had demonstrated the absence of any new indigenous cases. In such circumstances, eradication of malaria would have been achieved. In 1959, the WHO revised the criteria for the eradication of malaria: (a) the absence of transmission; (b) the end of residual endemic illness; (c) the non-use of measures to control carriers and no routine chemotherapy coverage for three consecutive years (p.307). 
Although in 1958 the Eighth Report ( $8^{\text {th }}$ Report..., set. 1960) produced new criteria to establish the eradication of malaria, the main requirement remained unaltered: the absence of indigenous cases for three years. The maintenance stage began following confirmation of the eradication of malaria. This stage consisted in strict epidemiological surveillance against the reintroduction of the disease. The strategy for the global eradication campaign proposed by the WHO, therefore, involved the standardization of measures adopted in different countries, creating a single model to be followed by all.

In this way, the campaign for the eradication of malaria prescribed by the WHO represented a model for public health. This model would be guided by a top-down policy, i.e. programs to eradicate malaria should be the same in any part of the world. As a fundamental part of the campaign, it should be noted that there was a lot of confidence in scientific knowledge and techniques as ways of ensuring a successful outcome of the campaign and of any investment in public health. In the "age of development," technically based solutions, which included planning measures of a normative kind, indicated standards of intervention in public life which were understood in terms of inputs and outputs. In other words, given a technical intervention, the expected and planned consequences would result from it (Rivera, Artmann, 2012).

Reality, however, showed itself to be much more complicated and challenging. There were concerns with regard to the resistance that carrier mosquitoes attained against the main kind of technical intervention of the period: DDT. These concerns ended by providing the basis for one of the main arguments for a global eradication campaign with the features we have discussed above. In the case of the malaria eradication campaign, DDT was the problem and the solution. It was a problem because it lost its effectiveness, it was the solution because it was the principal instrument for eliminating the disease.

The choice of malaria as the most serious illness affecting the world population in the 1950s, however, did not immediately have the same impact in the member-states of the WHO. Brazil was one of the countries in which malaria existed, but it did not seem to be serious any more. At least that was the implication of the public health program put forward by the then presidential candidate, Juscelino Kubitschek (JK). Written by the medical health expert Mário Pinotti, director of the National Malaria Service (SNM), the program made a connection, classic for the time, between health and development. For him and for other health professionals of the contemporary vanguard, disease was partly responsible for poverty and the backwardness of underdeveloped nations. According to JK and Pinotti, the medicine of the 1950s enabled a classification to be made of the principal diseases into three main groups.

The first group consisted in the so-called pestilential diseases which, for Juscelino, had already been conquered by the pioneering achievements of Rodrigues Alves and Oswaldo Cruz. The third group of diseases comprised degenerative pathologies such as cancer and cardio-vascular ailments, which were of lesser importance when compared with the diseases of the second group. The latter, in his view, were the diseases which required the attention of the authorities, the mass diseases par excellence: malaria, tuberculosis, leprosy, verminous infestation, yaws, and others, considered responsible for prejudicing the development of countries (Programa..., 1955, p.4).

Despite the fact that little or nothing is disclosed in the literature dealing with the JK government, the then candidate Juscelino had an exclusive program of targets for public 
health, in an attempt to resolve the main questions facing public health in Brazil. Without abandoning this debate, the main focus of this article is the course taken by the Malaria Control and Eradication Working Group in Brazil, in its varying relationships with the arguments and guidelines established at international level, particularly in the context of the WHO.

It is interesting to analyze the way in which locally defined interests affected the outcome of the directions issuing from Geneva. The conflicts between the most varied interests, from political and institutional concerns, through the specialist communities, down to the public bureaucracies, gave rise to a context which produced important consequences for the reception, in Brazil, of the directions for the eradication of malaria as a global public health problem in the post-war scene. Divided into two parts, the first part of the text discusses the tensions surrounding the debate over the control and/or the eradication of malaria. Far from being a simple dispute over technical terminology, what was at issue in the context of the years 1950-1960 was the definition of priorities in the Brazilian public health agenda.

In the second part of the text, we discuss the outcome of the fight against malaria at the beginning of the period of military rule, when the National Program for the Eradication of Malaria was set up, in an apparent compliance by the Brazilian government with the ordinances of the WHO. In the last part of the text, we draw up a balance sheet, looking at the part played by various interests in the country and the fading of malaria as a central public health question, both in Brazil and internationally.

\section{The Malaria Control and Eradication Working Group}

There was no immediate adhesion in Brazil to the global plan for the eradication of malaria prepared by the WHO. A historical analysis of the fight against malaria in the country suggests that the building of a certain national tradition in the control of the disease also served to create political and scientific resistance to the plan. Paradoxically, this tradition of malaria control had its roots in the successful instance of the eradication of the carrier Anopheles gambiae.

In any event, for the Malaria Experts Committee of the WHO in 1955, the principal objective of the eradication programs was the extinction of the disease, while the control programs which had been tested up till then aimed only at a reduction in transmission. The Brazilian government accepted the eradication plan proposed by the WHO in 1955 . However, the Malaria Eradication Campaign (MEC) would only be made official ten years later, through specific legislation to this effect. Law 4.709/65 amended law 2.743/56 and created the MEC, repealing decree-laws 43.174/58, 14.494/58 and 50.925/61 (Brasil, 1967, p.4).

Legislation before 1965 seems to have served to prepare or convert the existing malaria prevention and control programs to eradication plans, which is slightly curious, because the WHO and the international financing agencies had a clear policy in the matter: funds were only available for eradication programs. In terms of policy statements, Brazil reflected the international pronouncements, but in practice remained faithful to the doctrine of control. At the end of the day, Brazilian experts did not regard the malaria situation with the same degree of gravity as the views espoused by the WHO ( $7^{\text {th }}$ Report..., 1957, p.7). While the 
WHO prescribed a preparatory phase of one year for countries to pass specific legislation for the campaign and to put in hand an immediate transformation of their control activities to eradication programs, in Brazil this initial phase lasted for more than three years (Brasil, 1966, p.36).

However, as we have already said, the Brazilian government did not blindly follow these recommendations, which in some cases were referred to as "demands" on the part of the WHO and the US government. How can we explain this ambiguity on the part of Brazil with regard to the recommendations issued by the WHO for the eradication of malaria? We should remember that the second half of the 1950s was an appropriate time for negotiations in the international context.

The international context was dominated by the Cold War. Latin America, the countries of which were essentially exporters of agricultural produce and raw materials for the USA and other advanced capitalist countries, suffered from precarious health conditions among its population and from social inequality (Hobsbawm, 1995, p.350-351). The discontent among large social sections of these countries began to concern the US government, which in the post-war environment was engaged in the maintenance and expansion of its influence in the region, principally through the financing of economic and social programs. The period saw an increase in efforts to contain the socialist model propagated by the USSR (Campos, 2006).

The government of Juscelino Kubitschek fitted into the same context. JK tried to put into effect the policies which had been defined in his Manifesto, a series of measures which aimed at the industrialization and modernization of the country. By 1958, however, it was already clear that he was encountering difficulties in conducting the government and obtaining the necessary investment which would make his Manifesto a reality. Vizentini (2004, p.89) says that Kubitschek adopted a nationalist position in bargaining with the USA. JK took advantage of the conditions created by the Cold War to negotiate bilateral agreements with the US government. The question of continental security became the occasion for initiating a dialogue with Washington.

In 1957, Washington formulated the Eisenhower Doctrine, which was intended to confront nationalism and left wing movements in the Third World. Although this policy had been created because of the outbreak of war in 1956 and the political radicalization of the Middle East, it was of general application, and there was cooperation with the CIA (Vizentini, 2004, p.95-96).

According to Vizentini (2004, p.96), the period between the suicide of President Vargas in August 1954 and the launch of Operation Pan-America in 1958 can be characterized as a kind of "hiatus between the foreign policies of the populist phase". After 1958, there was a return to a policy which sought to occupy a more independent position in relation to the US and an attempt to establish bilateral cooperation agreements. As regards public health, these agreements were advantageous for the Brazilian government, which obtained substantial funds for the maintenance of malaria control programs, even though these were not the programs recommended or demanded. ${ }^{2}$ However, the resources provided by international agencies were not sufficient, and the financial question was always identified as a problem which impeded 
the eradication program. The doubts about how to structure the campaign were responsible for the maintenance of the control programs. In the reports of the eradication campaign in 1961, the National Department for Rural Diseases (DNERu) was identified as the institution which was freezing and manipulating the funds.

However, the Campaign, structured within a government department and without any flexibility in the handling of funds, was in no condition to carry out the program which had been planned. The worsening financial position had negative consequences for the department, whose 'control' programs had descended to such a level that the figures for malaria started to become alarming. It was necessary to find funds to increase spraying in these 'control' areas, and in 1959 the amount of spraying in 'control' areas was almost equal to that carried out in eradication areas. These factors weakened the Campaign, where competent direction did not succeed in achieving its targets through the fundamental elements in an eradication plan: continuity, intensity and periodicity (Brasil, 1967, p.37).

In 1953, the Ministry of Health was separated from the Ministry of Education, and three years later, as we have seen, the DNERu was created. The basic function of the DNERu was to organize and carry out investigation work and lead the fight against mass disease, more particularly the rural epidemics which assailed the populations of the interior of the country, where there were always health threats. As from 1958, the DNERu also "directed"3 the Malaria Control and Eradication Working Group (Brasil, 1967, p.4).

In examining the public health program of Juscelino Kubitschek, it can be seen that malaria was considered to be a problem which had almost been overcome by the control program dating from 1941. In other words, in the area of public health, we can see from the documents that malaria was not the biggest health problem faced by the Brazilian people. The fact that malaria was not a priority in the field of public health in Brazil reflects in part the attitude adopted by the government: faithful to the accustomed practices of control, but out of harmony with the recommendations of the WHO. It would not be long, however, before the first sign of a change of course in the government's policy for the eradication of malaria came with the creation of the Malaria Control and Eradication Working Group in 1958.

Decree-law 43.174, of 4 February 1958, established a working group charged with planning and executing the eradication of the disease in Brazil. The GTEM was established within the DNERu and comprised the following members: the director-general of the DNERu; the coordinator of the DNERu's Campaign Against Malaria; and the Brazilian representative of Point IV in Brazil. ${ }^{4}$

The GTEM was chaired by the director-general of the DNERu. In the same year, a change in the law decided that the Working Group should come under the command of the Ministry of Health. The Brazilian government signed cooperation agreements with the Pan-American Health Department and with the International Cooperation Administration (ICA) of the US government (Noticiário, 1958, p.213).

According to the then Minister of Health, Mauricio Medeiros, the GTEM was established to "accommodate" the demands of the WHO and to "respect" the wishes of the American government. The Pan-American Health Department and Point IV were engaged in assisting Brazil with regard to the eradication of malaria. These two institutions demanded that their 
assistance was passed on to a specialist body devoted exclusively to the eradication of malaria. The GTEM was set up on the basis of these interfaces of interests and national structures. In the words of Medeiros:

I declare the establishment of the Working Group, which has been created within the National Department for Rural Diseases to satisfy the 'demands' of the World Health Organization and to 'accommodate the wishes' of the American government. The former, through the Pan-American Health Department, and the latter, through Point IV, are prepared to assist Brazil with the problem of eradicating malaria. Both wish this help to be given to a specialist body devoted exclusively to the problem of eradicating malaria (Noticiário, 1958, p.214).

In greeting the members of the Working Group, Medeiros announced his desire for the program to be carried out within the specified timetable. The Minister of Health took on the commitment with the WHO campaign without discussing the cultural and geographical peculiarities of Brazil. He believed that by following the WHO and ICA guidelines, Brazil would achieve the eradication of malaria. The attitude of Medeiros is one of total compliance with what he called the demands of the WHO, but in practice the Brazilian government took another view. ${ }^{5}$

The malaria area of Brazil amounted to $7,747,398 \mathrm{~km}^{2}$, a large part of the entire national territory, and the GTEM was responsible for the preparation of a working plan which prescribed the execution of a control and eradication program by stages, in accordance with pre-selected geographical areas. The areas to be covered by the eradication program were very limited in 1958. It was the control program that prevailed in most of Brazil. The idea put forward by Pinotti for the maintenance of the malaria control policies was to introduce the MEC gradually, without prejudicing results already obtained and considered positive, in other words, not to interrupt the control program until the eradication program had reached the entire area of the country affected by malaria.

The GTEM commenced its activities in the North East region, employing DDT as its principal weapon in the fight. For the Amazon region, chloroquine was the method chosen (Brasil, 1964, p.1). The promise that the control program would be maintained for a short time was not fulfilled. In addition, the initial stage of the eradication campaign lasted longer than planned. To defend this situation, it was argued that there was a "lack" of resources to proceed in the manner prescribed by the WHO. The Brazilian malaria experts, particularly Pinotti, were comfortable with regard to the incidence of malaria in Brazil. However, according to Pinotti and JK, malaria would become a threat in the country after 1958. In practice, it did not represent a serious public health problem.

As we have seen, the DNERu was established in the early months of the Juscelino Kubitschek government, and incorporated the National Health Services set up in 1941. The priority for the new institution was represented by the diseases that affected the inhabitants of rural areas. The choice of malaria as the principal illness threatening humanity, the "creation of the need" to eradicate it, was not enough to create the same sense of seriousness in the Brazilian context. The DNERu was a movement in a direction contrary to the WHO recommendations, being a department which was responsible for various endemic rural diseases. Everything 
indicates that the scientific community and the Brazilian health bureaucracy were going in the opposite direction to that prescribed by the WHO.

In fact, the programs for combating malaria in Brazil were successful examples of control for other rural diseases. According to JK, in 1946 there were still eight million persons suffering from malaria, and the disease was present from the Amazon region to Rio Grande do Sul. 26 million Brazilians lived in regions where the disease was endemic. ${ }^{6}$ However, Kubitschek claimed that, through insecticide spraying programs and the treatment of the sick with antimalaria drugs, the disease was reduced to low levels of incidence and the number of infected persons fell to a figure of two hundred thousand. In his words:

This spectacular reduction, which was achieved in such a short time, was of the order of $97 \%$. Malaria was almost abolished in Brazil, we achieved a great victory. But our technical and scientific resources were not enough. It was and will always remain necessary that, along with modern technical and scientific resources, there is a competent and dedicated team of specialists, organized and led by men such as Mário Pinotti (Programa..., 1955, p.16).

During his government of Minas Gerais State (1951-1955), Kubitschek signed agreements with the National Malaria Service (SNM) for the control of malaria and Chagas disease, which resulted in health programs associated with his priorities of electrification, industrialization and the construction of roads to modernize the state. For JK, the experience of malaria control policies provided three basic lessons to serve as a model for future health policies in Brazil. The first lesson was that the technical and financial resources for undertaking effective health programs must be substantial and available. The second lesson was that such resources and programs must be managed by competent professionals situated outside the political environment. The third lesson was that the competence of Brazilian public health professionals should be exemplary and capable of overcoming obstacles and difficulties of every kind. As we have indicated, JK saw the malaria control policies at the time as a model for health policy. For him, the malaria control program had overcome enormous obstacles, both with regard to resources and to the size of the territory involved. The program was successful in practically eradicating the disease (Programa..., 1955, p.24).

On 11 March 1958 the Working Group set up to eradicate malaria in Brazil was officially inaugurated. THE GTEM contained the persons who had been principally concerned with rural diseases: Mauricio Medeiros, the Minister of Health; Mário Pinotti, president of the Working Group; Fernando Bustamante, coordinator of the MEC; Guilherme de Aragão, Brazilian representative for Point IV in Brazil; E. Ross Jenney, the representative of ICA; Kenneth O. Courtney, the representative of the Pan-American Health Department; and Antônio Franco de Oliveira, secretary of the Working Group (Noticiário, 1958, p.213).

At the inauguration of the Working Group, Mário Pinotti made a speech guided by his belief in the eradication of malaria, in which he took up a position which was very different from what he wrote in his preface to Programa de saúde do candidato Juscelino Kubitschek (1955). As already mentioned, at the beginning of the Juscelino government, Pinotti and the President did not regard malaria as such a serious public health question. Malaria was seen as a successful example of a public health policy based on the control of the disease - a health problem which had almost been overcome. 
In a revised perspective, Pinotti drew up a balance sheet for the malaria control program developed principally by the National Malaria Service (SNM) in the 1940s, and by DNERu from 1956 onwards. According to Pinotti, with the discovery of DDT and its mass use after the Second World War, an almost complete coverage of the whole of Brazilian territory was achieved. The Federal District, for example, had not recorded a single indigenous case since 1951. The situation was the same in 114 municipalities in which malaria had been eradicated. For Mário Pinotti, the success of the Brazilian control program was due to the structure and organization of a service primarily concerned with the application of DDT in the home (Programa..., 1955, p.27).

In 1958, therefore, at the official inauguration of the Working Group, as president of the GTEM, Pinotti displayed a deep concern with the malaria situation in the country. He made a speech stressing the need to take rapid action against the disease. The weapons identified by Pinotti in the fight for eradication were DDT and chloroquine (Silva, Hochmann, 2011), DDT for direct use against the mosquito, chloroquine to combat the parasite in the blood. The period stipulated for the eradication of the disease was five years, in line with the recommendations of the WHO. However, Pinotti took the opportunity to state that the target could only be achieved with the help of the US government, represented by Point IV. He predicted that, without such help, Brazil would not achieve the eradication of malaria for at least seven years.

Now, what I want to stress is the following: even with the control program, there has been a huge capital investment in the economic recovery of vast areas of the country, which had earlier been completely abandoned. It is sufficient to say that in 1940, with a population of 40 million inhabitants, our estimate was that there were 8 million cases of malaria in Brazil, whilst now, in 1957, with a population of 62 million, we have only 250 thousand cases of malaria. Obviously this has led to a major economic recovery in Brazil. ... Your Excellency, we now have the capacity to pursue a program for the eradication of malaria. This is firstly because the Government, thanks to the concern always shown by Your Excellency, has allocated us a larger budget, secondly because we have the cooperation of the American government, as represented by Point IV, which means 'significant help' in the eradication campaign, and finally because of the Pan-American Health Department, which is always part of work of an international nature (Noticiário, 1958, p.216).

Because of his career achievements, Pinotti was appointed president of the Working Group. His work as a health expert and his leadership of the SNM and the DNERu made him an almost unanimous choice. His name was given to the chloroquined salts method which was intended to be the Brazilian contribution to the global fight against malaria. In this context, his speech regarding the gravity of the malaria situation in Brazil in 1958 was intended to impart seriousness of purpose to the proposal submitted by the Brazilian government for the eradication of malaria. The appeal by Pinotti for financial help for the campaign was answered, in part, because of the recognition afforded to his work. He was the leading authority on malaria in Brazil. His commitment to the eradication campaign does not seem strange, if he really believed that malaria represented a grave national public health problem. Could it be that he had in fact changed his view? (Programa..., 1955, p.31). 
For the coordinator of the Working Group's eradication campaign, Fernando Bustamante, the campaign for the eradication of malaria throughout Brazil was not an easy undertaking. One of the problems that the program had to face was the Amazon region. The epidemiological conditions in the region, related to the biology of the most common carrier, Anopheles darlingi, would constitute the first difficulty. Other serious threats to the campaign would be represented by the type of dwellings, the way of life of the inhabitants, and the administrative problems associated with the size of the area and its low population density. For these reasons, Bustamante was one of the advocates for the use of chloroquine (Silva, Hochmann, 2011).

Bustamante (1959), in a similar speech to that of Pinotti, stipulated, as a basic condition for the conversion of control policies to eradication programs, an increase in funds for the campaign. In other words, the eradication plan would be more expensive and would only be possible if financial help was forthcoming from international agencies. Eradication would be possible, but at a cost which would be more than some countries could afford. The institutional structure would be very important for the operation of the eradication campaign, along with the experience of Brazilian malaria experts, who could ensure the success of the campaign. However, according to Bustamante, there was resistance on the part of politicians and malaria professionals with regard to the eradication programs.

In the view of the later, maintenance of the control programs was necessary, because they were considered to have been very successful. Brazil was already on the way towards the eradication of malaria. Adopting the eradication program would involve expenditure that the government could not meet. In Bustamante's view, the control program was responsible for the creation of a structure which "could" be useful in implementing the eradication plan. What we can conclude is that the control program was sometimes seen in a positive light, as being well-structured and capable of giving an impulse to the eradication campaign. Because it was considered a success in Brazil and cost less, the arguments for maintaining this kind of program were very strong in practice. In theory, we can see that there were efforts to produce arguments that were in line with the proposals of the WHO.

According to the coordinator of the GTEM, the concept of control was used in studies of malaria and in public health in order to determine the application of measures whose purpose was to reduce the incidence of the disease, without such reduction necessarily leading to eradication. In Brazil, the fight against malaria was based mainly on the application of measures against the breeding grounds of the carrier mosquitoes; thus, a reduction in the incidence of the disease meant, basically, a reduction in the density levels of the carriers.

There were cases in which malaria control measures were taken in the form of the application of insecticides, without producing any reduction in the density levels of the carrier mosquitoes. This type of control could also be combined with the use of residual action insecticides such as DDT. Anti-malaria drugs were also used in control programs. Bustamante lists the principal medicines against malaria which had been developed after the Second World War. According to him, quinine was the most important remedy for almost three centuries, the prophylactic drugs such as chloroquinine ((Aralen, Resoquine, Nivaquine B), amodiaquine (Camoquim), proguanil (Paludrina), perimetamine (Duraprin) and primaquine being the most effective. 
Finally, the ground for the eradication of malaria in Brazil was prepared, and the specialists were ready with their experience and new methods, but the funds were still lacking to start the campaign. The GTEM had been created as the body responsible for managing the campaign. It also represented, as we have seen, an "imposition" by the agencies which were financing the WHO eradication campaign. The ICA, as part of Point IV, made its assistance for the campaign conditional on the creation of an institution which was dynamic and had a certain degree of autonomy.

The creation of the GTEM was the first stage in the commitment of the Brazilian government towards the global eradication campaign, and the first condition for obtaining the funds required to start a national eradication program. In the planning of the WHO specialists, the Working Group had one year to ensure the passing of specific legislation for eradication policies and the conversion of control programs, and this did not occur. The constant complaint was lack of resources. The requirements of the WHO and the US government were not absolute. In the case of Brazil, there were informal negotiations, which allowed the malaria control actions to be maintained for quite a time. However, according to Rachou (1960, p.333-334), there were factors which made the operation of the eradication programs difficult:

We have to bear in mind the habits of certain species of anopheles. Although endophilia is an almost constant feature in the behavior of the carrier species, there are carriers with pronounced exophilia, which bite humans away from their houses, thereby transmitting the parasite outside the home ... there are certain human activities which must be protected. Certain sections of the population, such as prospectors, rubber tappers, etc., through the nature of their work, lead a nomadic life, changing their location constantly and having no fixed abode; they do not have houses which can be sprayed with insecticide so as to give them protection against the transmission of malaria ... consideration must also be given to the types of houses in certain regions. There are houses without walls, or with very few walls, which therefore provide little or nothing in the way of surfaces for the spraying of insecticide ... and there are certain regions which are very thinly populated, of enormous extent, and which lack any means of communication, making it difficult, and sometimes impossible, to carry out regular applications of insecticide to the home.

Rachou defended the use of the Pinotti method as an alternative means of combating malaria, but at the same time he pointed out the problems involved in the idea of eradication, which was the basis for the global campaign. These problems made it impossible to proceed in accordance with the plans and recommendations of the WHO. The maintenance of control practices was justified but was not approved by the agencies that were promoting the campaign. These difficulties which occurred in a national context helped in negotiating and obtaining assistance. The funds would overcome the obstacles and confirm the commitment to the eradication campaign (Rachou, 1960, p.332).

In 1958, this commitment was more in the nature of a promise than a concrete action. The speeches of Pinotti and JK in 1955, which confirmed the disease as a question of public health which had been resolved, strengthened the control programs (Programa..., 1955). However, compliance with the WHO proposals could be, for the JK government, a way of compensating areas which had been neglected because of the resources which had been 
channeled towards meeting the government's targets, owing to the construction of Brasilia and the financial crisis in the middle of his term of office (Vizentini, 2004, p.100).

In this sense, the planning for the transformation of the control program into a malaria eradication policy was only a formal compliance with the WHO recommendations which had been put forward in 1955. The WHO required the creation of autonomous and administratively decentralized bodies (institutions) to plan and execute the eradication campaign. The GTEM was the body created to fulfill this role, but the DNERu, through Pinotti, controlled the actions of the GTEM. Bustamante also refers to malaria as a grave problem in a speech in 1958. In this context, malaria was presented as the most serious problem of public health, with between 200 and 250 million people infected throughout the world. The area of its highest incidence was the continent of Africa, which had no access to the most advanced prophylactic techniques. However, Bustamante firmly believed that the structure and national tradition in the control of the disease would ensure the success of any eradication program in Brazil. According to him, the elimination of malaria was more of a financial and administrative problem than a technical one. The Health Minister, Mauricio Medeiros, on the occasion of the inauguration of the GTEM, claimed that malaria in Brazil was under control and that progress would be made to the eradication stage without problems. According to the Minister, the malaria eradication program had been initially planned to be completed within a period of five years, which could be extended to six or seven years. In other words, the maximum period for the eradication of malaria in Brazil was seven years:

The American concerns center on the fact that it is not possible to conceive of the eradication of a disease transmitted by insects if the work is not coordinated between the various nations of the continent. As the American government and the World Health Organization are concerned with the eradication of malaria throughout the world, and consequently throughout the South American continent, it is essential to have the collaboration of Brazil, which, as far as I am aware at the present moment, is one of the few countries which has not agreed or signed up to the international plan (Noticiário, 1958, p.214).

According to Aragão, who was the Point IV representative in Brazil, the inauguration of the GTEM was the crowning achievement of the national campaign for malaria control, led by Mário Pinotti. For Aragão, the GTEM represented another phase in the campaign, which aspired to be international. In other words, the GTEM would link up with the global plan for eradication proposed by the WHO. Aragão believed that, in addition to linking the malaria control campaign with the GTEM, there should also be administrative continuity (Noticiário, 1958, p.215).

The period beginning with the proposals for the eradication of malaria at the $14^{\text {th }}$ PanAmerican Health Conference (1954) and the Eighth World Health Meeting (1955) coincides with the presentation of his public health program by the then candidate Juscelino Kubitschek in 1955. As we have shown, at the start of the JK government, malaria did not assume a larger importance to the detriment of other rural diseases. It is only in 1958 that measures are adopted along the lines proposed by the WHO. The creation of the GTEM, initially subordinate to the DNERu, was a timid step in the direction of the WHO proposals. The JK 
government ended in 1961, without having completed even the initial stage of the Malaria Eradication Program, which provided for the passing of specific legislation.

In 1961, the GTEM underwent its first modification. An emergency plan was issued to rectify the planning failures of 1958. By this stage, neither Mário Pinotti nor JK were in power. Pinotti, having left the Ministry of Health the previous year, retired from public life and from his activities as a malaria expert. The use of chloroquine salts began to be questioned in a national context (Hochmann, 2008, p.182-183; Silva, Hochmann, 2011). The DNERu was partly blamed for the critical situation in which the campaign found itself. The administrative structure of the DNERu, by its centralization of funds and programs, made it impossible for the GTEM to function properly (Brasil, 1967, p.37). Three years after its inauguration, during the Jânio Quadros government, the role of the GTEM was altered by decree-law 50.925, of 7 July 1961, which established that the GTEM should be the body responsible for the planning and execution of all malaria control and eradication programs in the country. The direction of control and eradication activities was united in one body.

As a result of this understanding, the government published a new Decree, which reunited the Campaign and granted it more autonomy. The old executive board was replaced by a directorate; new funds were brought in to remedy the serious deficiencies in personnel, insecticide and essential equipment; and new fronts were opened up on the battlefield. The 'Emergency Plan' was assigned a period of 2 years, at the end of which the control activities would be absorbed by the eradication program (Brasil, 1967, p.36).

The team which comprised the GTEM in 1958 was changed, principally the executive board, which became a directorate. The emergency plan of 1961 marks the end of the activities of a group which had coordinated the malaria control programs for more than a decade. Pinotti, through the SNM and the DNERu, had been at the head of activities against the disease since 1942, and remained in charge of these institutions despite the changes of government. Up to the beginning of the 1960s, the GTEM had been an arm of the DNERu, brought into the malaria control campaign run by that institution. In the first three years, the GTEM was always subject to the direction of Mário Pinotti, both within the DNERu and in the Ministry of Health.

After 1961, the program became known as the Malaria Control and Eradication Campaign (MEC), and would be carried out in accordance with a new plan prepared by the Malaria Eradication Working Group. This new plan provided for greater autonomy for the campaign and a gradual decrease in control activities. The execution of the MEC was to take place in two stages. The first, of an emergency nature, was intended to link the preparatory phase with the attack phase, which affected geographical recognition, the progress from cycle to cycle, and sought to cover the entire malaria regions of the country. ${ }^{7}$

The second stage corresponded to the moment of full coverage (eradication). The new Working Group comprised: the minister of health; the director-general of the DNERu; the director-general of the National Health Department; the director of the Special Service Foundation for Public Health; the director of the MEC; and the Brazilian government representative for Point IV (Brasil, 1965, p.1-2). The difference between this GTEM and the 1958 version was that the DNERu had less influence on the campaign. In other words, control activities continued to operate, but diminished as funds were increasingly directed towards the eradication campaign. 
At this stage Brazil had still not converted its control program into an eradication campaign. Data from PAHO showed that the conversion had only begun in certain locations in the North East region. The Pinotti method was widely used in the Amazon region, and figured in the international reports as an activity in the combat against malaria. However, as from December 1961, chloroquine stopped being used and Amazonia reverted to the preparatory stage of the campaign. The questioning with regard to this method, in a national context, had started with the departure of its creator. One year later, international criticism reappeared and pointed out various failings (Silva, Hochmann, 2011).

The director of the MEC, Mário Pinotti, appointed by the minister of health, was a technical expert from the Ministry of Health of recognized competence. In his job, his principal task was to extend the MEC to the whole country. His powers and duties were equivalent to those of the director-general of the DNERu in matters concerning malaria, and he had the power to apply budget funds, special credits and extraordinary credits.

In this context, we can observe the growth of the campaign politically and economically. At the political level, the MEC was the equivalent of the DNERu, to which it had previously been subordinate. At the economic level, Ministry of Health funding of the MEC in 1961 was about twenty times greater when compared with 1958, and approximately four times greater than the funding obtained from the United States Agency for International Development, $\mathrm{PAHO}$ and the WHO. The main structure of the MEC included the directorate, comprising the Technical and Administrative Audit; the International Technical Section and the Epidemiology Sections; the sections for Insecticide Operations, Health Publicity and Training; and the section for Administration, Transport and Supply (Brasil, 1965, p.2).

Privileged regions during this period were the frontier areas where Brazil borders with other countries and adjoining territories. The principal method employed was the spraying of these regions with insecticide. Parts of Brazil were at the maintenance stage (epidemiological surveillance) in 1960: (a) the states of the North East region; (b) parts of the South East region, such as the south of Minas Gerais and the State of Guanabara; (c) Santa Catarina and the northern coastal area of Rio Grande do Sul (Brasil, 1965, p.2-3).

At the end of this cycle, we can say that the three years of commitment by the JK government to the WHO eradication campaign were marked more by speeches and promises than by concrete actions towards the elimination of malaria. The creation of the GTEM in 1958 brought together a group of malaria specialists led by Mário Pinotti with wide experience in the control of the disease. The recently created DNERu, a centralizing body for the national campaigns against rural diseases, employed its administrative structure to direct the activities of the GTEM. The DNERu managed the funds and gave preference to control activities, contrary to the wishes of the WHO and the international assistance agencies sponsored by the American government - a policy which was partly sustained by the positive results of the control program, where Pinotti was considered the greatest Brazilian authority on malaria. The health expert-politician who had masterminded the chloroquine approach succeeded in extending the initial stage of the campaign by three years, always blaming the lack of funds. The retirement of Pinotti from the Ministry of Health in 1960 and, consequently, from the DNERu and the GTEM, inevitably led to administrative changes in the direction of the campaign. 


\section{The MEC after 1961}

In 1965, under the military government, the MEC was finally made official, through the passing of specific legislation, as the WHO had directed. The Working Group and the Malaria Control and Eradication Campaign were abolished. To assist the Ministry of Health, a Consultative Council for the Eradication of Malaria was created, whose job it was to deal with technical, administrative and operational matters in the program to fight the disease in Brazil. The council was headed by the minister of health, with assistance from the directors of the DNERu and the DNS, along with representatives from the Finance Ministry and from the departments for Planning and Economic Coordination and for Coordination of Regional Bodies. Also involved was the director of the MEC and the representatives of the international agencies (Brasil, 1967, p.4 e s.).

The main aim of Law 4.709, of 28 June 1965, was to supply the Ministry of Health with the legal and administrative tools for an effective fight against the disease, by seeking to make the National Program for the Eradication of Malaria more flexible. Among the various provisions in the law, we should mention: (a) direct subordination to the Ministry of Health; (b) autonomy to contract and pay temporary specialist personnel under the same conditions that applied to civil servants; (c) basic details of the budget and the manner of its disbursement; (d) exemption from taxes on the import of materials and equipment. According to Armando Augusto Saraiva Filho, legal adviser to the MEC, the legislation for the campaign was innovatory and decentralizing, which was surprising in view of the political context in which it was created. In the words of Saraiva Filho:

On 12 November 1965, by Decree 57.244, the President approved the provisions of this Law, which established, among other matters, the administrative structure of the body, where we can see the innovatory tendency in the decentralization of decisionmaking, in the sense of strengthening the Regional Councils and allowing them to resolve immediate problems at their own level, thereby avoiding a pile up of decisions to be taken centrally. Along with these features, the legislation for the MEC also created a Planning Group (article 42), whose purpose was not only planning, but the provision of assistance to the Directorate in everything relating to the technical and administrative programs required to achieve the targeted aims (Brasil, 1967, p.3).

The Brazilian government signed understandings and agreements with international agencies to underwrite the operations of the malaria eradication program. The two main sponsors which took part in the introduction of the MEC in Brazil were the US government's Agency for International Development (AID), which continued to represent the ICA and Point IV, and the WHO, represented by its regional office, the Pan-American Health Department (RPAS), a subsidiary of PAHO. The US government supplied the MEC with vehicles, equipment, marine engines, insecticide, solvents, microscopes, chemicals etc. Help from the US amounted to US\$13,252,390.00, or 26\% of the total MEC budget, in the period between 1958 and 1964 . The agreement was renewed in 1964 for a further year, when the AID supplied the same materials in the form of a loan of US\$ 6,500 thousand (Brasil, 1967, p.37-38).

To summarize, the evolution of the Brazilian malaria eradication program, according to the MEC reports, comprised three stages: the Eradication Plan (1958), with the establishment of 
the GTEM; its reformulation in 1961, with the creation of the Emergency Plan; and finally the National Plan for the Eradication of Malaria (1965), which transformed the control program into an eradication program. 1958 saw the first efforts to transform control measures into effective eradication activities. The initial phase of the plan was prepared at the end of 1957. In 1961 it was estimated that 3,534,515 homes had been covered, at the end of the attack phase. Eradication was achieved in 1967, according to the MEC reports. In reality, what had been planned did not occur:

So many problems affected the plan devised in 1958 , that the need to revise it started to become urgent. This revision led to the so-called Emergency Plan, under which in the chemical spraying of 'control' areas the new idea of simultaneous geographical recognition was introduced, along with other measures specially designed for the preparatory phase. This was the best way, perhaps the only way, to contain the disease at acceptable levels in the areas which had not benefited from eradication measures (Brasil, 1967, p.36).

In 1969 , the $22^{\text {nd }}$ World Health Meeting proposed the classification of malaria areas into short and long term eradication areas. The WHO still believed that eradication would be possible, even if it took a longer period. In the 1970s, it became clear that this belief was unsustainable, for epidemiological, entomological, economic and social reasons which prevented long term eradication. In Brazil, the MEC and the DNERu were abolished in 1970, the year the Public Health Campaigns Directorate (Sucam) was set up. The MEC had not been totally successful in Brazil, but the transmission of malaria had been blocked in the North East, South East, Center West and South regions (Loiola, Silva, Tauil, 2002).

\section{Final considerations}

In the preceding sections we have discussed the history of the Working Group for the Control and Eradication of Malaria in Brazil. The initiative was typical of post-war efforts, when health started to be seen as an important sector for national development. International cooperation, especially with specialist multilateral bodies, was perceived in this context as one of the principal strategies for achieving higher living and health standards for the peoples of the world and for promoting economic and social development.

The process of formulating and implementing an agenda for international cooperation involves not only matters which are considered "necessary" or "priority," but also resources to be employed in programs for achieving higher living standards or social development.

The experience of the Working Group which we have discussed in this article reveals that the principles defined in international forums are subject to constant pressures from the different interests comprising the national political scene - particularly the bureaucracies and the specialists.

We have witnessed a process of constant disagreements - where the tensions and contradictions are not always totally apparent - between the WHO and the policies adopted by the Brazilian health authorities. It can also be seen that the principles and guidelines of the top-down policies of the WHO, as regards the international plan for the eradication of malaria, suffered important modifications owing to the particular circumstances prevailing in 
Brazil. The interpretation suggested is that, in Brazil, the standard plans proposed by the WHO were modified to take account of specific social realities, political institutions in transition, and a well-developed tradition in public health and malaria studies. A historical analysis of the MEC in Brazil reveals, therefore, the ways in which Brazilian health policies concurred with, or diverged from, the programs of the international and multilateral agencies.

An analysis of the MEC developed in Brazil shows that efforts to convert the control programs into national eradication plans occupied more time than the campaign itself. The preparatory phase of the MEC lasted around seven years (1958-1965), while the period recommended by the WHO was just one year. Eradication programs started in 1958, with the creation of the GTEM, but the decree-laws did not amount to specific legislation for the campaign, which was only passed in 1965 . The WHO recommendations envisaged the legal constitution of the MEC during this preparatory period. Until 1965, eradication activities were combined with control activities.

Throughout the 1940s, a malaria control structure had been built up in Brazil. The National Malaria Service and the Public Health Special Service made a decisive contribution towards this structure which, during the 1950s, would be transformed at great cost. In this sense we can describe a health policy with much experience in combating malaria in Brazil. The malaria control programs achieved positive results, which led the president himself, Juscelino Kubitschek, to consider that malaria was not a very serious threat to worker health. In the documents of the time and in the speeches of JK and his allies in 1956, malaria was a public health question which had almost been resolved. The success of certain campaigns and of the so-called national health services was reflected in the improvements to public health policies in the 1950s. The splitting up of the Ministry of Education and Health in 1953, the creation of the DNERu in 1956 and the inauguration of the GTEM in 1958 are important examples of public health changes in a national context. The creation of the GTEM, particularly, shows the catalyst role played by international agencies, through their offers of funding, with regard to the national health agenda.

The MEC was not successful at a global level. Malaria was not eradicated globally, only in certain countries. The causes of this "failure" are not fully known. One of the possible reasons for the lack of interest in eradication on the part of the richest countries is that they had already resolved their problems with regard to malaria. These countries were the main sources of finance for the global campaign.

Our analysis has been confined to the period corresponding to the JK government, a short but extremely important period, linked with optimistic antecedent factors and decisive precedents. From the creation of the Ministry of Health in 1953, until the official confirmation of the MEC in 1965, we have the government of Juscelino with its public health program, the DNERu and the GTEM. We also have international recognition of the work of Brazilian malaria experts, particularly the work of Mário Pinotti and his methods for combating malaria. The Pinotti method was utilized and recognized by PAHO as a technique for eradication in the Amazon region. However, at the end of 1961, the chloroquine program was discontinued in the region - Pinotti was no longer part of the campaign or the government.

The malaria eradication campaign advocated by the WHO only became a reality in Brazil in 1965. In the 1970s the WHO recognized the failure of the MEC on a global scale and 
declared that eradication would be impossible for epidemiological, entomological, economic and social reasons. Late in the day, there had been confirmation, in an international context, of the skeptical view taken by a substantial number of Brazilian malaria experts and by the Brazilian health bureaucracy.

\title{
NOTES
}

\begin{abstract}
${ }^{1}$ According to Emilio Pampana, director of the Malaria Eradication Division of the WHO, the malaria eradication program in 1956 consisted of four consecutive phases: preparatory phase; attack phase; consolidation phase; and maintenance phase. The preparatory phase would comprise three stages: preeradication research; planning; and preliminary operations. The stage of research and preparation of operations plan is the first step in the whole program. And the preparatory phase properly speaking begins after the conclusion of planning, following specific legislation passed by governments. The preparatory phase normally lasted one year and included the following: (a) recognition of the geographical region in the country affected by malaria; (b) entomological and epidemiological studies of the region; (c) organization of a national malaria eradication service, recruitment of trained personnel, acquisition of equipment and establishment of laboratories, workshops and research centers; (d) organization of public health education as regards the eradication of malaria; (e) realization of a pilot plan for total coverage by DDT spraying (Pampana, 1966, p.303).
\end{abstract}

${ }^{2}$ An emergency plan was created in 1961 to resolve the problems that had arisen at the beginning of the campaign in 1958. The maintenance of control activities was one of these problems (Brasil, 1967, p.37).

${ }^{3}$ Mário Pinotti was director of the DNERu, and was responsible for the malaria control campaign. Pinotti was also president of the GTEM, which was charged with implementing the eradication program.

${ }^{4}$ Point IV was part of a series of foreign policy measures adopted by the Truman government. Point I aimed at preparing programs which would strengthen the United Nations; Point II was a commitment to the economic recovery of European countries devastated by war; Point III established collective security mechanisms, through the North Atlantic Treaty and the Treaty of Rio de Janeiro; and finally Point IV was concerned, through the medium of mechanisms for international technical cooperation, with the export of technology and capital to less developed countries.

${ }^{5}$ A. Horwitz (1960, p.161), director of the Pan-American Health Office, when making an assessment of malaria eradication in 1960, pointed out that "problems of an administrative and financial nature made it difficult to develop the campaigns in Brazil, Panama, Paraguay and the Dominican Republic". Antônio Menezes (1968, p.1), head of the Administrative Division of the MEC, made a speech in 1966 at the opening of the "Course in malaria eradication for professional personnel," in which he quoted the words of the director-general of the WHO in 1960, Macolino Candau, who said that "governments were not prepared to concede administrative and financial authority to their malaria programs".

${ }^{6}$ These details originated in the book by João de Barros Barreto (1940) on the basis of inferences from the case of India.

${ }^{7}$ The cycle corresponded to the period of six months DDT spraying (Brasil, 1964, p.4).

\section{REFERENCES}

$7^{\text {th }}$ REPORT...

$7^{\text {th }}$ Report on The Special Malaria Fund of Paso. $10^{\text {th }}$ Meeting Pan-American Sanitary Organization and $9^{\text {th }}$ Meeting World Health Organization. Washington, DC. 1957.

$8^{\text {th }}$ REPORT...

$8^{\text {th }}$ Report on the Status of Malaria Eradication in the Americas. $12^{\text {th }}$ Meeting Pan- American Sanitary Organization and $12^{\text {th }}$ Meeting World Health Organization. Washington, DC. set. 1960.
BARATA, Rita Barradas.

Malária e seu controle. São Paulo: Hucitec. 1998.

BARRETO, João de Barros.

Malária: doutrina e prática. Rio de Janeiro:

A Noite. 1940.

BRASIL.

Ministério da Saúde. Relatório do Plano Nacional de Erradicação da Malária: operações para quinquênio 1967-1971. 1967. 
BRASIL.

Ministério da Saúde. Relatório do Plano Nacional de Erradicação da Malária: operações para quinquênio 1967-1971. 1966.

BRASIL.

Ministério da Saúde. Campanha de Erradicação da Malária. 1965. Relatório da Campanha de Erradicação da Malária e Relatório do Serviço de Erradicação da Malária e Profilaxia da Doença de Chagas (SEMPDC) do Estado de São Paulo: Quinta Reunião de Diretores de Serviço de Erradicação da Malária da América do Sul. Buenos Aires, Argentina, 6 a 11 de dezembro de 1965. 1965.

BRASIL.

Ministério da Saúde. Campanha de Erradicação Da Malária (CEM). Poços de Caldas, Minas Gerais. Quarta Reunião de Diretores de Serviço de Erradicação da Malária da América do Sul. Junho, 1964. Relatório da Campanha de Controle e Erradicação da Malária e Relatório do Serviço de Erradicação da Malária e Profilaxia da doença de Chagas (SEMPDC) do estado de São Paulo. 1964.

BROWN, P.J.

Failure-as-success: multiple meanings of eradication in the Rockefeller Foundation Sardina Project, 1946-1951. Parassitologia, v.40, p.117-130. 1998.

BUSTAMANTE, Fernando Machado. Considerações sobre certos problemas especiais relacionados com a erradicação da malária no Brasil. Revista Brasileira de Malariologia e Doenças Tropicais, v.11, n.1, p.9-17. 1959.

CAMPOS, André Luiz Vieira de.

Políticas internacionais de saúde na era Vargas: o Serviço Especial de Saúde Pública, 1942-1960. Rio de Janeiro: Fiocruz. 2006.

CUETO, Marcos.

El valor de la salud: historia de la Organización Panamericana de la Salud. Washington, DC: Organización Panamericana de la Salud. 2004.

HOBSBAWM, Eric J.

Era dos extremos: o breve século XX: 1914-1991. São Paulo: Companhia das Letras. 1995.

HOCHMAN, Gilberto.

From autonomy to partial alignment: national malaria programs in the time of global eradication, Brazil, 1941-61. CBMH/BCHM, v.25, n.1, p.161-192. 2008.

HORWITZ, Abraham.

Erradicação da malária. Revista Brasileira de Malariologia e Doenças Tropicais, v.15, n.1, p.191. 1960.
JACKSON, J.

Cognition and the global malaria eradication programme. Parassitologia, v.40, p.193-216. 1998.

LOIOLA, Carlos Catão Prates; SILVA, C.J.

Mangabeira da; TAUIL, Pedro Luiz.

Controle da malária no Brasil: 1965 a 2001.

Revista Panamericana Salud Publica/Pan-American

Journal Public Health, v.11, n.4, p.235-236. 2002.

MENEZES, Antônio Henrique.

Administração - Campanha de Erradicação da Malária: organização e estrutura. In: Brasil.

Relatório do primeiro Curso de Erradicação da

Malária para pessoal de nível profissional no Brasil. Brasília: Ministério da Saúde/DNERu. 1968.

NOTICIÁRIO.

Noticiário. Revista Brasileira de Malariologia e

Doenças Tropicais, v.10, n.2, p.213. 1958.

PACKARD, Randall.

No other logical choice: malaria eradication and the politics of international health in the postwar era. Parassitologia, v.40, p.217-229. 1998.

PAMPANA, Emilio.

Erradicación de la malaria. México: Editorial Limusa-Wiley. 1966.

PROGRAMA...

Programa de saúde pública do candidato Juscelino Kubitschek. São Paulo: L. Nicollini. 1955.

RACHOU, René.

O Método Pinotti nas atuais campanhas de combate à malária. Revista Brasileira de Malariologia e Doenças Tropicais, v.12, n.2, p.329-337. 1960.

RACHOU, René.

Atual estratégia da luta contra a malária. Revista Brasileira de Malariologia e Doenças Tropicais, n.4, p.8-9. 1956.

RIVERA, Francisco Javier Uribe; ARTMANN, Elizabeth.

Planejamento e gestão em saúde: conceitos, história e propostas. Rio de Janeiro: Fiocruz. 2012.

SILVA, Renato da; HOCHMAN, Gilberto.

Um método chamado Pinotti: sal medicamentoso, malária e saúde internacional (1952-1960). História, Ciências, SaúdeManguinhos, v.18, n.2, p.519-543. 2011.

VIZENTINI, Paulo Fagundes.

Juscelino Kubitschek: do retrocesso à barganha. In: Vizentini, Paulo Fagundes. Relações exteriores do Brasil (1945-1964): o nacionalismo e a política externa independente. Petrópolis: Vozes. p.89121. 2004. 